\title{
Learning for Life: The People's Free University and the Civil Commons
}

\author{
HOWARD WOODHOUSE \\ College of Education, University of Saskatchewan
}

\begin{abstract}
This article stems from the author's experience as one of the organizers of an alternative form of higher education, which drew its inspiration from the civil commons. In the early years of the new millennium, the People's Free University of Saskatchewan (PFU) offered a wide variety of courses to members of the public without charge, adopting as its founding principle the belief that "Anyone can learn, Anyone can teach." As a form of community-based education, the PFU accommodated the needs and aspirations of a diversity of individuals and groups too often denied by "research-intensive” universities. The civil commons itself is a web of interlocking institutions based on the life-code of value, which strengthens the public interest and enhances the growth of organic life. Unlike the money-code of value, whose goods are only available to those who can pay, the goods of the civil commons are accessible to all. This inner logic enables a full realization of life value as exemplified in the living tradition of popular university education.
\end{abstract}

The civil commons is the organized, unified, and community-funded capacity of universally accessible resources of society to protect and to enable the lives of its members as an end in itself. (McMurtry, 1998, p. 376)

\section{Introduction}

The market model currently undermining universities in Canada threatens education at its core. The opposition between education's logic of value and that of the corporate market is clearly defined by Professor John McMurtry (1991) as follows: "The aims and processes of education and the market are not only distinct, but contradictory” (p. 38). The contradiction is between education as a public process whose goal is to share knowledge among those seeking it and the market's goal of making ever more money for private individuals and companies. Professor Janice Newson (1992) explains this oppositional character in the following terms: "The principles that benefit markets undermine the objectives of education and conversely, education that achieves its intended purposes cannot serve well as a marketable commodity” (p. 234). Whereas private money profits are acquired by “a structure of acquisition that excludes others from their appropriation ... knowledge ... is acquired

Correspondence Address: Howard Woodhouse, Educational Foundations, College of Education, University of Saskatchewan, 28 Campus Dr., Saskatoon, SK S7N 0X1, Canada. Tel.: +1 306 966-7522; Email: howard.woodhouse@usask.ca

ISSN: 1911-4788 
by a structure of appropriation that ... is maximized the more its accumulation is shared by others" (McMurtry, 1991, p. 38). ${ }^{1}$

The struggle against the market model by faculty, students, and staff striving to sustain a learning process in which knowledge is shared rather than privatized has taken several forms. Egregious violations of academic freedom and integrity of research have been resisted, as in the case of Dr. Nancy Olivieri; there have been national campaigns against government cuts to higher education; and alternative kinds of university education have been established to counter the market model (Woodhouse, 2009). This article draws upon my own experience as someone who has written about and has been actively involved in such developments. In particular, I consider the market model in relation to the University of Saskatchewan (U of S), and analyze the People's Free University of Saskatchewan (PFU) that established a community of learners as a process of "friends educating friends" (Collins, 1994). In both theory and practice I have felt the power of the civil commons as a social agency capable of animating alternative possibilities to the market model. Understanding the civil commons is "the required act of social comprehension from which awakening out of the thrall of the global market value program follows" (McMurtry, 2001, p. 265). While a full realization of how the closed value system of the corporate market is opposed to all those institutions offering unpriced goods has yet to occur, there are signs of a growing understanding of its life-threatening character. The article reflects a commitment to "the emerging international struggle for life" and the ways in which the civil commons can sustain the necessary "will to act” (Woodhouse, 2001a, p. 231).

\section{The Emergence of the People's Free University}

In the year 2000, a report of the Research Committee of Council of the U of S declared that the goal of the University was to become "one of Canada's leading research universities in the next decade." The need "to increase research productivity ... [and enhance] our profile as a research-intensive university" was central to this program. The phrases "research intensiveness," and "research competitiveness" were repeated mantra-like as part of becoming "fully committed to the research enterprise” (Research Committee of Council, 2000, pp. 2, 4, 7). In a subsequent report, the Corporate Administration of the University made clear what this meant: "the university is knowledge ... [and] we need to ask ourselves if we should be marketing ourselves and this knowledge and not providing it for free" (Corporate Administration, 2005, p. 5). Knowledge created at the University of Saskatchewan was no longer to be publicly shared and disseminated, but bought and sold for private monetary gain.

The valorization of the "research-intensive" university represents a clear departure from the institution's past when the "excellent reputation ... [which] the University did and does have" was built primarily on its claim to be "the people's university" (Hayden, 1983, p. 305) This founding ideal was articulated by the first president, Walter Murray, in 1909: "There should be ever present the consciousness that this is the university of the people, established by the people, and devoted by the people to the advancement of learning and the promotion of happiness and virtue" (Hayden,

Studies in Social Justice, Volume 5, Issue 1, 2011 
1983, p. 295). The advancement of learning had as its goal at that time the common good of the people of Saskatchewan. Murray's unequivocal message is that all knowledge advanced at the $\mathrm{U}$ of $\mathrm{S}$ was to be shared with all the people of the province.

The paradigm shift away from "the people's university" can be gauged in at least three ways. The quality of undergraduate education declined as a result of budget cuts and the loss of 130 faculty positions. This resulted in larger classes, fewer professors to teach them, and little opportunity for dialogue or critical thought (Findlay, 2003; 2010). Second, a greater emphasis was placed on research conducted for the market as a direct result of federal funding agencies requiring "partners" from industry to provide matching funds, thereby exerting leverage over the nature and goals of research (McMurtry, 2010; 2011) —an injunction consistent with the "Innovation Agenda" requiring universities to "bring new goods and services to market" (Report of the Expert Panel on the Commercialization of University Research, 1999, p. vi). Third, the centralization of university governance was advanced through the mechanisms of Integrated Planning and Systematic Program Review, which pit academic departments one against another in the zero-sum game of resource allocation (Quigley, 2003).

It was in this context that the PFU was founded. A series of public meetings organized on campus in the Department of Educational Foundations, entitled " $U$ of $S$ Ltd: W(h)ither the Corporate University?", was the first real opposition to research intensiveness and the Innovation Agenda and was supported by the U of S Faculty Association. The series was surprisingly well attended, including faculty from the applied sciences, who had "concerns about the over-determination of an Innovation Agenda which, otherwise is widely viewed as favoring their particular research interests" (Collins, 2003a, p. 49). Coupled with these forums on corporatization were student rallies opposed to the rise in tuition fees, as well as meetings which took place off campus about the need for an alternative form of higher education, including a panel discussion at the public library which attracted one hundred and fifty people (Collins, 2003b).

The PFU first opened its doors in the fall of 2002. Two hundred students between the ages of 12 and 82 from different social classes and ethnic backgrounds enrolled in six courses. Content varied from Aboriginal spirituality to music and politics, Canadian legal and political systems, psychology, human rights, and literature for personal growth. So successful was this initial semester that winter courses ranging in length from four to twelve weeks started in March of 2003 on such topics as globalization, human ecology, health care ethics, music, psychology, and community building, drawing fewer students in what was a bitterly cold season. In the fall term, three courses were offered on scientists questioning science, building global consciousness, and public law in Canada, as well as a series of café discussions on such topics as alternative budgets, politics in the city, factory farming, the criminalization of dissent, and agriculture in the global marketplace. In the winter of 2004, courses on astronomy and Canadian law were given in addition to café discussions on music, poetry, and civic politics.

The PFU provided learning experiences to anyone regardless of their ability to pay. Not only were courses offered free of charge, but a philosophy of inclusiveness stated that "Anyone can learn, Anyone can teach," an approach first adopted in slightly different form by the Free University Movement in the United States 
(Draves, 1980). In practice, this meant that qualified people from the community as well as recognized university teachers provided learning opportunities to many adults who could not otherwise afford higher education. In the words of one such student, this experience was "informal, informative, enjoyable, and educational." Courses took place in a variety of accessible locations, and those offered at St. Thomas Wesley United Church in one of the poorest core neighbourhoods of Saskatoon attracted the largest number of students during the first semester. Public lectures and forums as well as hands-on workshops on gardening, composting, success in the workplace, and putting together a resumé and learning portfolio were scheduled in the spring and fall of 2003. A conscious effort to balance practical and theoretical subjects in ways that appeal to the interests of students was a cornerstone of the PFU.

\section{Social Justice, the PFU, the Civil Commons, and the Money-Code of Value}

The tradition of social justice to which the PFU belongs is that of a prairie socialism, whose goal is the development of an "activated citizen" capable of understanding the forces driving capitalism by dialoguing with others and taking action to create a society which enhances the capacities of all its members (Welton, 1987). The philosophical framework articulated by McMurtry, based on the civil commons and an increase in life-value, enables an inclusive understanding of the pedagogical practices of the PFU. I explicate the meaning and implications of these core concepts below.

The civil commons is an interlocking set of institutions supporting and promoting life by providing universally accessible life goods such as publicly funded education, health care, and clean air and water. The regulating principle of the civil commons is that money is used to increase life-value by sustaining or enhancing the capacities of "society's members and their environmental life-host" (McMurtry, 1998, p. 24). An increase in life-value "consists in or enables a more coherently inclusive range of thought/feeling/action" (2008, p. 2). In order to realize growth in life-value, certain basic requirements to each of these dimensions of human life must be met. As Professor Jeff Noonan (2010) puts it:

\footnotetext{
We cannot live if our organic requirements are not met, we cannot think, reflect, evaluate and act as agents if certain socio-cultural requirements like caring mutualistic relationships, education, and meaningful work are denied us, and we cannot do anything freely if our lifetime is nothing but imposed routines; we need an experience of time as an open matrix of possibilities if we are to develop our capacities freely. (p. 7)
}

Hence the criterion of life-value is the extent to which the range and depth of each person's capacities are realized. The goal of the PFU was to enable anyone to enhance their capacity to learn regardless of their ability to pay.

In contrast, the money-code of value, which has characterized the global market since the $19^{\text {th }}$ century can be expressed as follows:

$$
\text { Money --------- Commodity for Sale ---------- More Money }
$$


Here, "more money, not more life, is the regulating objective of thought and action" (McMurtry, 1998, p. 299). Whereas the goods of the civil commons are accessible to all, the private goods of the money-code are available only to those who can afford to pay. A second "lethal mutation" (p. 301) has now come to dominate the corporate market and the formula for "this decoupled money-sequence" is:

$$
\text { Money -------- More Money ------- More Money }
$$

The transformation of money inputs into increased money outputs, which has "no productive contribution required in between" (p. 301), takes the form of currency and derivatives speculation, arbitrages, and leveraged takeovers to liquidate assets, traded for trillions of dollars that "daily destabilize or deplete public and private sectors, with interest rates on their speculations written off” (pp. 301-302).

\section{A Community of Adult Learners}

Advocates of the PFU were determined to establish an institution grounded in the history of both "the people's university" and the province itself-a history characterized by social democracy, the cooperative movement, and the struggle for social justice. The power of adult education to promote dialogue and enliven critical awareness among the general populace has been a central feature of all these movements. Although its goals have been ambiguous at times, adult education has been a distinctive feature of Saskatchewan's history. Farmers who formed the Wheat Pool in the 1930s went on to educate themselves about economics, politics, current affairs, literature, and philosophy, while many listened regularly to the Farm Radio Forum during the 1940s, discussing ideas and reading books so as to improve their education. In the mid-1940s, the newly elected Cooperative Commonwealth Federation government of Tommy Douglas launched a grass roots, radical, adult education program which, according to Professor Michael Welton, was "a massive campaign of study-action throughout the province- to begin the building of a new society." This society would be built on the concept of an "activated citizen," one who understood scientific and technological change, was aware of the causes of fascism and war, and "committed to playing an intelligent role in the constructive life of the community." Although the goal envisaged by the campaign's leader, Watson Thomson, to create a province that could "boast it is truly possessed by its people” (Welton, 1987, pp. 154-159) was not fulfilled, a legacy of community based education was firmly established.

Participants at an organizational meeting of the PFU in February 2002 drew upon this historical experience to articulate a distinctive value system which they believed should guide the new institution:

1. The PFU should be a place for all citizens to have access to knowledge, education, and research with classes located throughout the community.

2. University education should be a universal right, and should be of the people and for the people, offering opportunities for self-directed learning. 
3. The PFU should bring educators to work in the community together with citizens, meeting their needs, sharing knowledge, and enabling them to better understand their relationship with the world. It should be understood that a need is that without which life's capacity is always reduced (McMurtry, 1998, p. 164).

4. The principles of open access, equity, and participation must be respected; such practicalities as daycare and transportation costs should be covered in order for low income women, in particular, to participate.

5. The PFU should be an institution respectful of the marginalized and inclusive of Aboriginal peoples; anti-racist education and sensitivity to issues of class, race, gender, disability, and inner city communities should be stressed.

6. The curriculum should be both academic, stressing critical thought, and practical, enabling skills development in such areas as organic farming, traditional healing, indigenous arts and culture etc.

7. The curriculum should also be interdisciplinary in nature with an emphasis on people's economics, sense of place, community living, peace, environmental sustainability, people's history, and cooperative philosophy, using community resources and participatory research in an effort to include multiple perspectives.

8. The organizational structure should be an autonomous and "bottom-up" organizational structure, with decisions made democratically through consensus; concerted efforts should be made to build links with labour, rural communities, and community groups engaged in broad approaches to education.

9. The PFU should provide an education for empowerment, an avenue for people to overcome their oppression by providing services designed to narrow the gap between rich and poor (People's Free University, 2002, pp. 1-5).

At the core of this ambitious program is the idea that education is an integral part of the community. In practice, this suggests a relationship between students' life experience and their learning in which each is deeply affected by the other. The institutions of family, church, labour unions, women's organizations, Aboriginal bands, Métis groups, and professional associations all play a role in the educative activities of the PFU (Woodhouse, 2003). Lifelong learning, "as a process of man's [sic] growth toward fulfillment as an individual as well as a member of many groups in societies" (Faure, 1973), is a cornerstone of this approach, according to which students learn through a process of growth that is fully integrated with their lives. Relationships with others are important because they nurture their potential for learning, not simply as future employees but as citizens who participate in a variety of social contexts. By providing lifelong learning in this inclusive sense, the PFU set itself apart from the market model of education, whose goal is to produce a workforce that will retrain whenever new skills are required "to compete in the global market” (Woodhouse, 2009). Sharing community-based knowledge in an effective manner requires educators to be aware of the limitations of their own value

Studies in Social Justice, Volume 5, Issue 1, 2011 
systems as well those of their students. A frank recognition of the ways in which teachers at the PFU were privileged by virtue of their own education and social status was necessary, since this might separate them from some of their students. A process of questioning emerged in which teacher and student used their experience to critically examine collaborative ways in which to understand and interpret reality (Freire, 2006). Dissatisfaction with current modes of education and training, as well as valuable suggestions for reform were brought to light. One of the dangers in this process was dichotomous thinking; namely, the tendency to divide reality into a simplistic us/them form in which the PFU was by definition good and the regular university system bad. The ambiguities and complexities of community basededucation had to be acknowledged in order for the process of knowing to have real worth. The goal throughout was to provide participants with opportunities to express their full range of thought, feeling, and action in order for learning to flourish (McMurtry, 2005). This process involves the enhancement of thought through the use of both the imagination and conceptual abilities; of feeling as the growth of sentience and the emotional life; and action as animate movement through time and space (McMurtry, 1998, p. 298).

This was precisely the ideal of the original system of free universities in the United States, as articulated by Bill Draves (1980), one of its historians and founders. A diverse model of higher education provided "a new vision of what it means to learn" supported by "a "community of scholars,"” in which "a feeling of learning with others" was sustained by "a new concept of learning-as a process that anyone can tackle at any point." By unlocking barriers to knowledge traditionally regarded as the domain of the privileged, free universities promoted "a deluge of possibilities for people to learn and act” (p. 21). It was in this same spirit that faculty at the PFU offered their services free of charge to students who themselves chose to attend courses out of a desire to learn. Together they shared knowledge in ways that strengthened a sense of what education might become.

At the PFU, this approach led to an imaginative conception of learning grounded in a sense of community outside of the money-code of value. In the words of Professor Michael Collins (2003b), education was conceived as "very much a public good in contrast to calculating market-driven 'knowledge economy' imperatives." The idea of "friends learning from friends ... prefigures a radical restructuring of educational systems for ordinary men, women, and children." (pp. 1, 3). A community in which knowledge was shared as a public good among colleagues and friends served the needs of ordinary people by providing an alternative model of education from that of the market. According to one instructor, freedom from an exclusive emphasis on job training enabled students at the PFU to engage in the pursuit of knowledge in imaginative and critical ways.

Nor is this surprising, since the imagination may be the most potent force in the construction of any community. The imagination enables students and citizens alike to create alternative possibilities that challenge the status quo by considering ideas and practices that have not already been considered. It provides opportunities for freely engaging in constructive thought about ways to enrich the human condition and fortify those communities which make such flourishing possible. Adult learners at the PFU came to understand their need for knowledge as a process connecting them to one another as a band of imaginative scholars. Learning shared as a public good strengthened students' capacity to understand their many connections with 
reality - the local, the global, and the biotic community upon which we all depend. At its base, the value system of the PFU, like all cooperative and collaborative institutions, was based on life-value as whatever enables a more inclusive range of thought, feeling, and action. The PFU provided access for every member of the community "to grow and express themselves as human" (Sumner, 2005, p. 12).

\section{The Life-Code of Value and the Civil Commons}

The PFU, then, grew into a community in which the imagination and needs of learners were enhanced in a reflective space outside the imperatives of the “calculating market-driven 'knowledge economy"” (Collins, 2003b, p. 3). A value system which does not reduce knowledge to a commodity to be bought and sold is at work beyond money exchange for private profit which cannot in principle ever generate free exchange of knowledge as a good in itself. Consciously or not, the PFU presupposed a different code of value from the normative framework of the corporate market. The money-code of value, "which uses money to make more money for money managers and possessors,” (McMurtry, 2011, p. 6) moulds every activity to what brings higher returns on investment.

It is worth emphasizing, therefore, that the life-code of value is directly lifeenhancing in a way that the money-code can never be. Life has value quite apart from its instrumentalization in maximizing private money profits. Recognition of life's intrinsic value makes possible an understanding which transcends the limitations of the money-code in which life is simply a means to making more money for private money possessors. Two different sequences express how life is sustained by this value system, the first of which shows how life reproduces itself by holding its "capacities at their established scope" (McMurtry, 1998, p. 298):

$$
\begin{aligned}
& \text { Life ------ Means of Life ------- Life (Survival) } \\
& \text { (e.g. Food) }
\end{aligned}
$$

Here, someone who eats one square meal a day, for example, manages to survive, avoiding starvation and disease but has no vital energy left to engage in other "civilizing” activities that distinguish humankind. From a renewed perspective based on life, McMurtry (1998) argues, it makes little sense to ask "whether unpolluted water to drink or freedom from hunger or having a place to sleep is of value or disvalue," since these are preconditions for "the preservation and growth of our embodied being," and are recognized as "universal values" by cultures which differ in many other ways. To question whether freedom from hunger is good or bad is to disregard the human condition in which food (as well as clean air, water, and shelter) makes life possible. At its base, life as "organic movement, sentience and feeling, and thought" (pp. 19, 298) requires sustenance in order to reproduce itself. Only where basic survival needs are satisfied can questions about how to enhance life's range be addressed.

In the second, higher form of the life-code, in contrast, more life-value is the end term of the sequence (p. 298):

Studies in Social Justice, Volume 5, Issue 1, 2011 
Life ---- Means of Life ---- More Comprehensive Life (i.e. Growth of Life's Range)

(e.g. Education)

In this case, the life-code has evolved socially from the original one, since the process of education, which is one of the institutions constituting the means of life, provides "accessible learning conditions ... increas[ing] life value ... [so as] to widen or deepen them [human capacities] to a more comprehensive range” (1998, p. 298). One of the ways in which this range can be maximized is by enhancing humanity's capacity for learning. Universal access to formal and informal education with the goal of sharing knowledge among participants makes possible a more comprehensive understanding of subject matter and the world. This potentiality can only be realized where institutions are in place capable of creating the conditions for human learning as a good for all participants. McMurtry (1998) argues that an institutional nexus of this kind is immanent in all human societies despite the ravages of the corporate market in this era. The civil commons comprise the most civilizing aspects of human achievement and are distinguished by an ability to offer universal access to services which ensure the survival and growth of all organic life. Public education and health care are two examples, but clean water supply systems, public transit structures, housing for the poor and resources for the handicapped, public libraries, public arts and broadcasting, parks and wilderness areas, and public spaces for interaction and enjoyment of shared life are part of this same network. This intricate web of institutions is, in other words, "what people ensure together as a society to protect and further life, as distinct from money aggregates" (p. 24).

This inner logic to provide services enabling a more comprehensive range of life is in direct contradiction to the global market and a threat by its independence from knowledge growth as a mere means to money capital expansion. This is why global market agencies like the World Bank, demand that formally life goods are bought and sold in a privatized market order. A prime example is the Bank's advocacy of increased "tuition and full cost-recovery fees," limiting access to higher education to those who can pay, coupled with the need for universities to adopt "cost-effective, market-responsive learning" (Johnstone et al., 1998, p. 25). The overriding need to reduce unit costs means that the process of learning must, so the Bank claims, be accountable to the market and exclude all those unable to pay. ${ }^{2}$

Nevertheless, the civil commons extends beyond the lives of human beings to the preservation of nature in general. Since the earth is the source of all life, and human beings are dependent upon her for their well-being, she is to be valued as "the lifeground" for our very existence. Human responsibilities in this regard stem from our inter-relationship with all living organisms and from a preconscious recognition that they too constitute the future of the planet. This is expressed spontaneously as "a felt bond of being that crosses boundaries of membranes, classes, peoples, and even species" (McMurtry, 1998, p. 23) when we experience other humans, animals, forests, or different life forms torn apart, wasted, and threatened with extinction by life-blind corporate appropriation to maximize private money profits. 


\section{The PFU and the Civil Commons}

In this section, I argue that while the PFU was grounded in the life-code of value and its "instituted bearer" the "civil commons," the difficulties in sustaining it as an alternative learning community show that the civil commons was not well understood by its advocates. This is for two reasons: first, participants failed to grasp the strength of the civil commons in combating the money-code of value; second, they did not fully comprehend the significance of learning as a unified process in which the internal and external aspects of human beings are actively engaged. I go on to argue that this latter conception of learning, which McMurtry advocates, is consistent with the account given by Alfred North Whitehead.

The relationship between the civil commons and the PFU is an especially close one. As the creative link between mere survival and the full expression of human capacities in learning, the civil commons enables such life-enhancing activity in principle. The potentiality for teaching and learning capable of enhancing life's range was actualized through a network of people working together at the PFU in concrete ways. United by a vision of an alternative form of higher education serving the needs of people independently of their ability to pay, a web of students, community members, faculty, and staff made this a reality. A distinctive form of education came into being based on structures and processes which, in Professor Jennifer Sumner's (2005) words, "contribute to the civil commons ... [through] teaching, learning, collaborating, and researching” (pp. 113-114). The concept of universal accessibility enabling a fuller realization of life through education is a defining characteristic of both the civil commons and the PFU. Without this ideal and the educational praxis flowing from it as guide, the PFU's existence might not have been possible. The logic of value of the civil commons takes hold, McMurtry argues, in the form of "concepts and realities which are both material and spiritual in nature as humans themselves are.” By striving to satisfy the material and spiritual needs of teachers and learners, the PFU enabled both partners to share knowledge of use to the community. While avoiding the reduction of education to job training, it also sustained the many living connections between knowing and its social context. A balance was constantly sought between "the internal and external as an integral unity of process in which their division breeds inertia” (2001, pp. 264, 265). Learning as a dynamic process integrating the internal and external lives of participants constituted both the ideal and the baseline for the PFU's educational practice.

Why, then, is it so difficult to achieve and sustain a participatory learning community of this kind? Two reasons suggest themselves. First, the strength of the civil commons to counter the money-code of value and offer universally accessible, unpriced goods is still largely unrecognized. As McMurtry (2001) puts it:

The lifeground and its civil commons agency are so blinkered out by the ruling market mind set of our time, now becoming a totalitarian metaphysic in its imperialisation, that these grounds of human being are still unfamiliar even when named, defined, and connected in their meaning and presence across global societies. (pp. 264-265)

Studies in Social Justice, Volume 5, Issue 1, 2011 
Even when the power of publicly funded health care, education, libraries, wilderness areas, and radio etc. is fully analyzed, and its international significance and presence demonstrated, people are blinded by the money-code of value "inculcated in the mind as a ruling syntax of value and meaning" (McMurtry, 2008). "There is no alternative" (TINA) runs the mantra first chanted by Margaret Thatcher, which perfectly explains this reigning value code and syntax. This determinist position contradicts rational and critical debate as well as the idea of universities as seats of learning, leaving little room for the articulation of alternative ways of understanding or being in the world (Sumner, 2005, p. 5).

In a materialistic global society, it is increasingly difficult to imagine, let alone achieve, the "integral unity of process" in which "the external and internal" aspects of one's life are unified in the manner proposed by McMurtry. And here lies a second problem for an educational community like the PFU: how to conceive of learning as a process integrating the conscious and material sides of human beings? In order to make sense of this question and remain "open to argument that seeks just this comprehension," it is necessary to step beyond the bounds of much modern Western philosophical thought, which too easily accepts the "soul-vs-matter divide" as fact (McMurtry, 2001, pp. 265, 264). Whitehead is among those philosophers who attempt to bridge this gap. He conceives of learning as a "process of self-creation," which involves an awareness of our internal life as "a unity of emotions, enjoyments, hopes, fears, regrets, valuations of alternatives, decisions" through which we shape a "welter of material into a consistent pattern of feelings" as the basis for understanding the world. At the same time, we can "shape the activities of the environment into a new creation" in the form of projects, which are part of "a continuation of the antecedent world" and of our participation in a community of learners. As individuals in such a community, we entertain "the conceptual anticipation of the future" in the form of an "ideal," or "teleological aim," which is also "an enjoyment in the present" because it is part of what we become in "the immediate self-creation of the new creature" (1966, p. 166).

Put differently, we achieve an internal unity by integrating our experience in order to understand the world; and we can then act to change it on the basis of ideals enjoyed both in the present and as projections into the future. Throughout this process we are transformed by what Whitehead (1961) calls, "a wider sweep of conscious interest" in which "the removal of the stress of acquisitive feeling arising from the soul's preoccupation with itself" makes possible the "deep metaphysical insight" that organic life itself is the founding principle for the "coordination of values" (p. 285). Life-value, not the acquisition of money aggregates, becomes the goal of learning. Once emancipated from the demands of self-interest, this deep metaphysical insight becomes clear. On this central point, the PFU stands shoulder to shoulder with the organizing idea of the civil commons' evolution in which "Whiteheadian[s] [too] cannot support the marketization of the whole of society including education that is now so far advanced" (Cobb, 1998, p. 106).

\section{A Living Tradition}

The ideals concretized at the PFU enhanced life in ways currently frustrated by the corporate market model of education and the money-code of value which underlies 
it. Rather, the PFU subscribed to the life-code of value and to the interlocking institutions of the civil commons, which are "its historically instituted but unrecognized bearer and social agency” (McMurtry, 2001, p. 265). The PFU strove for an integral unity of process capable of satisfying the material and spiritual needs of ordinary people engaged in seeking and sharing knowledge among a community of learners-just as at another level the civil commons provides its members with their life needs though public health care, libraries, and wilderness areas. The internal impulse to pursue knowledge in conjunction with others was connected to a learning environment in which this potentiality became a reality. Moreover, the ongoing relationship with the $U$ of $S$, which was sustained through the participation of faculty and graduate students in both institutions was a considerable source of strength: "community-based initiatives that stay connected with our public institutions and boldly demand educational and other services in accord with the needs of ordinary men and women over corporate interests, can inspire the growth of a counter-hegemonic consciousness and the link between lifelong learning and participatory democracy" (Collins, 2003a, p. 53). The subsequent adoption of "University Outreach" as an official criterion for assessing the value of research and teaching in terms of its relevance to the broader community, coupled with monthly sessions of "Philosophy in the Community" undertaken by the Philosophy Department and supported by the Vice-President Research, are just two examples of the ongoing influence exerted by the PFU on the U of S.

Nor do civil commons projects like the PFU and life-value over money-value growth end in unfunded isolation. In France several popular universities have sprung up in recent years. The Université Populaire de Caen (UPC) in Normandy has offered courses, seminars, workshops, and art shows without charge since 2002. The program for the academic year 2010-11included seminars and workshops on biomedical ethics, politics, philosophy for children, film, contemporary literature, jazz, mathematics, architecture, psychology and music, women and society, and economics. The founder of the UPC, Michel Onfray, a philosopher who took early retirement in order to teach the "counter history" of philosophy, offered a course critical of the "left Freudianism" of Otto Gross, Wilhelm Reich, Herbert Marcuse, and Erich Fromm. The author of more than fifty publications ${ }^{3}$ also created the Université Populaire d'Argentan in 2006, and wrote the following in the manifesto for both institutions:

\begin{abstract}
D’où l'Université Populaire de Caen qui propose une douzaine de séminaires pour analyser et comprendre le fonctionnement du monde, puis avancer des alternatives à la négativité contemporaine. Nul ne l'ignore plus, notre époque se définit par la mondialisation sous sa forme libérale : l'argent fait la loi, le marché guide l'économie, certes, mais aussi la plupart des productions culturelles, les consciences, les relations entre les hommes - dans le cadre national, certes, mais aussi international. (Onfray, 2006) [italics mine]
\end{abstract}

The UPC, then, provides an education for ordinary people to understand the world by offering alternative visions to further global market totalization, which now controls the economy, culture, the relationships between human beings, the planet, and the very ways in which we think. Clearly opposed to the money-code of value, and in accordance with life-value and civil commons' principles, the UPC continues

Studies in Social Justice, Volume 5, Issue 1, 2011 
to flourish after nine years. Could it be that a civil commons formation in rural Normandy offers greater support to its educational functions than did Saskatoon? In fact, the vision of an open university beyond fees and bureaucracies is observable here in a borderless "concrescence" of resistance to and supercession of the moneycode of value in higher education as well as in common public infrastructures of clean water systems, air quality regulation, public life spaces, and integrated electrical grids. Yet, education holds a special place here. As McMurtry (1998) observes: "The world now moves for the first time in history to a global struggle between knowledge and misrepresentation as the finally contending forces” (p. 395).

\section{Notes}

1 In addition to education's opposing goals, its opposing motivations, methods, and standards of excellence to those of the market are analyzed in McMurtry, 1991, pp. 38-41; 1998, pp. 188-190; Woodhouse, 2001b, pp. 107-118; 2009, pp. 22-37.

2 In the face of mounting criticism the World Bank proposed a new form of social wealth calculation that went beyond money transactions "by integrating economic, social and environmental factors ... including education, nutrition and health care" (1995). This apparent respect for the goods of the civil commons is undermined by the Bank's conceptual inability to recognize structural conflicts with the money-code of value as conflicts (McMurtry, 1999, pp. 195-196).

${ }^{3}$ Onfray's most recent book published in April 2010 is a critique of Freud, titled Le crépuscule d'une illusion: La fabulation freudienne. Paris. Grasset.

\section{References}

Cobb, J. (1998). Beyond essays. Interchange. 29(1), 105-110.

Collins, M. (1994). Adult education as vocation. London \& New York: Routledge.

Collins, M. (2003a). The people's free university. In M. Collins (Ed.), Learning for life: A compendium of papers on lifelong learning (pp. 45-54). Saskatoon: Department of Educational Foundations, University of Saskatchewan .

Collins, M. (2003b). The people's free university: Counteracting the innovation agenda on campus and model for lifelong learning. Saskatchewan Notes: Canadian Centre for Policy Alternative,. 2(9), 1-4.

Corporate Administration. (2005). Business opportunities: Strategic directions, interview program summary. Saskatoon: University of Saskatchewan.

Draves, W. (1980). The free university: A model for lifelong learning. Chicago, IL: Association Press.

Faure, E. (1973). Learning to be: The world of education today and tomorrow. Toronto: Ontario Institute for Studies in Education.

Findlay, L. (2003, March). Out of step with the university “On the Move.” Vox, 1-3.

Findlay, L. (2010). Academic freedom, institutional autonomy, and the co-operative university. In J. Newson \& C. Polster (Eds.), Academic callings: The university we have had, now have, and could have (pp. 212-218). Toronto: Canadian Scholars' Press.

Freire, P. (2006). Pedagogy of the oppressed. New York, NY: Continuum.

Hayden, M. (1983). Seeking a balance: The University of Saskatchewan, 1907-1982. Vancouver, BC: University of British Columbia Press.

Johnstone, D.B., Arora, A. \& Experton, W. (1998). The financing and management of higher education: A status report on worldwide reforms. Washington, DC: The World Bank.

McMurtry, J. (1991). Education and the market model. Paideusis. 5(1), 36-44.

McMurtry, J. (1998). Unequal freedoms: The corporate market as an ethical system. Toronto: Garamond Press.

Studies in Social Justice, Volume 5, Issue 1, 2011 


\section{Howard Woodhouse}

McMurtry, J. (1999). The cancer stage of capitalism. London: Pluto Press.

McMurtry, J. (2001). The life code of value and the civil commons: A reply to three educators. Interchange. 32(3), 261-270.

McMurtry, J. (2005). Reclaiming the teaching profession: Standing up for the authority of learning. Our Schools/Our Selves. 14(2), 63-82.

McMurtry, J. (2008). What is good, what is bad: The value of all values across time, places, and theories. Philosophy and world problems. Oxford \& Paris: EOLSS. UNESCO. Retrieved from http://www.eolss.net

McMurtry, J. (2010). Beyond market self-serving: Recovering the academy's vocation. In J. Newson \& C. Polster (Eds.), Academic callings: The university we have had, now have, and could have (pp. 19-25). Toronto: Canadian Scholars' Press.

McMurtry, J. (2011). The university wars: The corporate administration versus the learning vocation. Vox. March, 1-8.

Newson, J. (1992). The decline of faculty influence: Confronting the effects of the corporate agenda. In Carroll, W., Christiansen-Rufman, L., Currie, R., \& Harrison, D. (Eds.), Fragile truths: 25 years of sociology and anthropology in Canada (pp. 231-249). Ottawa: Carleton University Press.

Noonan, J. (2010, May-June). G.A. Cohen and the ethical core of socialism: Equality or lifesufficiency. Paper presented at the Congress of the Humanities and Social Sciences. Montreal: Concordia University, Montreal.

Onfray, M. (2006). Le jardin (potager) d'Epicure. Retrieved from http://up-argentan.pagespersoorange.fr/michel-onfray.html.

People's Free University. (2002). Comments on a People's University. Saskatoon, SK: People's Free University. Organizing Meeting. February 4, 1-5.

Quigley, T. (2003). A study in top-down management. CAUT Bulletin. January, A13.

Report of the Expert Panel on the Commercialization of University Research. (1999, May). Public investments in university research: reaping the benefits. Ottawa: Government of Canada.

Research Committee of Council. (2000, January). Increasing research intensiveness at the University of Saskatchewan. Saskatoon, SK: University of Saskatchewan.

Sumner, J. (2005). Sustainability and the civil commons: Rural communities in the age of globalization. Toronto, ON: University of Toronto Press.

Welton, M. R. (1987). Mobilizing the people for socialism: The politics of adult education in Saskatchewan. In M.R. Welton (Ed.). Knowledge for the people: The struggle for adult learning in English-speaking Canada. Toronto: Ontario Institute for Studies in Education.

Whitehead, A. N. (1961). Adventures of ideas. New York, NY: The Free Press.

Whitehead, A.N. (1966). Modes of thought. New York, NY: The Free Press.

Woodhouse, H. (2001a). Ultimately life is not for sale. Interchange. 32(3), 217-232.

Woodhouse, H. (2001b). The market model of education and the threat to Canadian universities. Encounters on Education. 2, 104-122.

Woodhouse, H. (2003). Building Saskatchewan communities through education. Saskatchewan Notes: Canadian Centre for Policy Alternatives. 2(3), 1-4.

Woodhouse, H. (2009). Selling out: Academic freedom and the corporate market. Montreal, QC \& Kingston, ON. McGill-Queen's University Press.

World Bank. (1995). World Bank develops new system to measure the wealth of nations. [Press Release]. Office of the President. Washington, DC, 1-9.

Studies in Social Justice, Volume 5, Issue 1, 2011 